УДК 821.161.2-31.09 Процюк

Черниш Анна, кандидат філологічних наук, старший викладач кафедри української мови і літератури Сумський державний педагогічний університет ім. А. С. Макаренка

\title{
ІНТЕРТЕКСТУАЛЬНІСТЬ РОМАНУ С. ПРОЦЮКА «ТОТЕМ»
}

\begin{abstract}
Стаття присвячена аналізу інтертекстуальних маркерів у романі С. Процюка «Тотем». Найчисельнішими інтертекстуальними проявами у творі постають алюзї̈. Особливу інтертекстуальну ауру роману С. Прочюка «Тотем» витворюють оніми, з якими пов'язані стійкі асоціації як певні психокоди. Вагомого інтертекстуального звучання у романі додаютъ біблеїзми, иитати зі святого Писъма та образ Христа-Спасителя, що виступають готовими текстовими прецедентами для авторсъких розмислів $i$ художнъого паралелізму, відповідаючи за формування дискурсу спасіння, прозріння $i$ віронавернення. Особливого інтертекстуалъного звучання у романі С. Процюка набувае метафора йожефа менгеле як алюзія на прототип жсрстокого лікаря-експериментатора, що призводить до тотемозалежності / тотемоколінкування / тотемоплекання, засоційованого з людсъкою деструкиією, виродженням, облудливістю, гріховністю, аморалъністю, безчесністю $i$ безвілъністю. Алюзія на Йозефа Менгеле у романі мотивуе появу численних людсъких вад, увиразнюе мотив гріхопадіння $i$ віровідступнищтва, пояснюе психологічні коди низки неврозів, психозів, страхів, патологій y житті героїв. Інтертекстуалъними маркерами у романі С. Проиюка «Тотем» виступають епіграфи до окремих розділів твору, увиразнюючи авторсъку позичію $i$ суголосність цитованому, відзначаючисъ випереджалъним характером інбормування сюжетних колізій.
\end{abstract}

Ключові слова: інтертекстуалъністъ, паратекстуальність, алюзія, епіграф, деструкиія, психокод.

\begin{abstract}
Anna Chernysh. The Intertextuality of the Protsyuk's Novel "Totem". The article is devoted to the analysis of intertextual markers in S. Protsyuk's novel "Totem", stated in its own textual and paratextual relations. The most numerous in the intertextual dimension of the work are allusions. A special intertextual aura of S. Protsyuk's novel "Totem" is produced by those with whom persistent associations are associated as certain psychocodes. The characters' names execute meaningful load (Mary, Victor). Important intertextual sounding in the novel is added by Biblicalism, scripture quotes, and the image of Christ the Savior, who set ready text precedents for authorial reflections and artistic parallelism, responsible for shaping the discourse of salvation, insight, and conversion. In contrast to the God-centered intertextual line of the work in S. Protsyuk's novel "Totem" a number of destructive images, serving as serious psychological destructions, were used, expressing the motive of human degradation, sin, lust, immorality,
\end{abstract}


84 Літератури світу: поетика, ментальність і духовність. 2020. Bип.14

and pathologic behaviors and behavioral models - Maodzeduna, Caligula, Nefertiti with the characters of the novel; Victor's and his father's perversity, lust, and adventurism are paralleled by the vital postulates of Don Juan, Casanova and love-lovers. Special intertextual sound in the novel of S. Protsyuk acquires the metaphor of Joseph Mengele as an allusion to the prototype of a cruel experimenter, which leads to totem dependence / totemolinking, associated with human destruction, degeneration, delusionalness, sinlessness, immorality. The allusion to Joseph Mengele in the novel motivates the appearance of numerous human flaws, expresses the motive of sin and apostasy, explains the psychological codes of a number of neuroses, psychoses, fears, pathologies in the lives of heroes. Intertextual markers in S. Protsyuk's novel "Totem" are epigraphs to separate sections of the work, expressing the author's position and consonance with the cited, noting the pre-emptive nature of informing plot collisions.

Key words: intertextuality, paratextuality, allusion, epigraph, destruction, psychological code.

Постановка проблеми. Інтертекстуальний потенціал роману С. Процюка «Тотем» представлений алюзіями і ремінісценціями на попередні тексти культури, що $\epsilon$ смисловими кодами до роману українського письменника, а також паратекстуальністю і метатекстуальністю. Теорія інтертекстуального дискурсу отримала широку наукову інтерпретацію у студіях Ю. Крістевої, Р. Барта, Ж. Женетта, М.Фуко, У.Еко, Н. Фатєєвої, Н. П'єго-Гро та ін. Опираючись на наукові здобутки провідних фахівців із теорії інтертекстуальності, ставимо за мету виявити та проаналізувати інтертектуальні маркери у романі С.Процюка «Тотем». Твір українського письменника не поставав у центрі наукових зацікавлень, зокрема в інтертекстуальному вимірі. Відтак стаття відзначається актуальністю, зумовленою потребою з'ясувати інтертекстуальні прояви у романі С. Процюка «Тотем».

Виклад основного матеріалу. На особливу увагу у структурі роману С. Процюка «Тотем» заслуговують імена головних персонажів, що, безсумнівно, виступають одним із провідних алюзійних проявів інтертекстуальності, позаяк, як відомо, антропоніми виступають сконденсованим мікросюжетом твору, викликаючи певні стійкі асоціації з подальшим розвитком подій. Найвагомішого онімічного інтертекстуального звучання набирають імена Віктора та Марії, на чому повсякчас наголошує й автор роману.

Алюзійність використаних у романі імен пов'язана з ототожненням або, навпаки, семантичною невідповідністю антропонімів особливостям його носіїв у контексті певних художніх ситуацій. Так, найбільше уваги у романі С. Процюк приділяє функціонуванню імені головного героя Віктора, що у перекладі з латинської означає переможець. Однак 
семантичне наповнення антропоніму Віктор дисонує з психологічною природою його носія, який, як зауважено у романі, «від колиски переможений переможещъ» [1, с. 95]. Віктор, чиє ім'я символізує перемогу, має глибоку психоемоційну невідповідність із внутрішнім змістом антропоніму. Культуромовний зміст антропоніму головного героя суперечить психічній організації персонажа, породивши дискурс невиправданих і марних сподівань: «Твоє ім'я Віктор, себто переможець. Частенъко ім'я насміхаеться над власником. . . I несть числа мартирологу змарнованих $і$ занечищених імен, котрі не в силі підігрівати своїм первісним світлом дрібненьку мету $i$ куці помисли їхніх носїв» [1, с. 38]. Ім'я головного героя відповідає за формування пародійного анропонімічного виміру, що на думку Н. П'єго-Гро, виказує виразний інтертекстуальний потенціал твору [2]. 3 іменем Віктор найчастіше асоціюють вольових, сильних духом і тілом, готових до боротьби, енергійних, спраглих високого лету індивідуальностей, що разюче суперечить психокоду головного героя роману С. Процюка «Тотем». Своєю поведінкою Віктор створює прецедент сюру або пародії на власне спотворене й патологічне $Я$, глибоко травмоване численними неврозами, психозами, страхами, апатією, безвільністю, млявістю й марудністю існування. Вольове ім'я як кодоперемикач втрачає свою силу, не спроможне протистояти потужним психодеструктам, що руйнують персонажа на різних рівнях, викликаючи ненависть й агресію до самого себе: «I ти іноді ловиш себе на приступі ненависті не лише до свого імені, котре постійно занечищуєш брудом поразки, а і до всъого свого єства, позбавленого волі» [1, с. 38-39]. Відтак ім'я Віктора продукує появу спарадійованого дискурсу невідповідності, виступаючи ім'ям-насмішкою у житті героя.

На формування інтертекстуального онімічного простору роману С. Процюка «Тотем» впливає ім'я Марії - матері головного героя. Універсальність імені героїні відображає стійку біблійну асоціацію, обрамлюючи образ християнськими мотивами любові й жертовності, спонукаючи до асоціативного паралелізму з образом Діви Марії-матері, виповненої безмежної любові до свого стражденного сина. Промовиста алюзія на Божу Матір у тексті роману С. Процюка відповідає за міжтекстові зв'язки між прецедентним текстом - Біблією і текстом українського письменника. Алюзія на Діву Марію сприяе додатковому наповненню християнськими чеснотами героїні роману С. Процюка жертовності, гідності, честолюбності, праведності. 3 цього приводу слушною видається думка I. Гальперина, що «алюзія не конкретизуе добре відомий образ, а отримуе з нъого додаткову інформачію» [3, 
86 Літератури світу: поетика, ментальність і духовність. 2020. Bип.14

с. 110], увиразнюючи сакраментальність використання імені Марії у межах тексту С. Процюка. Інтертекстуальна значущість імені Марія у романі актуалізується з відповідною позицією матері Віктора жертви і страждальниці, яка своєю любов'ю прагнула врятувати й очистити дискурс зрадництва, відступництва, омани, гріхопадіння найдорожчих для неї чоловіків, які своїми вчинками продукували патологію і деструкцію свого існування, оскверняючи дарунок життя. Праведністю й аскезою свого існування Марія намагалася спокутувати провини, гріхи і відступництва свого чоловіка й сина, виправдовуючи християнське смислонавантаження свого сакрального імені.

Інтертекстуальний простір роману С. Процюка «Тотем» розширюють i доповнюють антропоніми біблійних постатей i цитат, уведених у текст твору з метою інтелектуального наповнення твору та психологічного паралелізму з образами головних героїв. Як стверджує Н. Єщенко, «біблійні вирази е прецедентними текстами, готовими інтелектуально-емоційними блоками, стереотипами, які вживаються як інтертекстуальні елементи, забезпечуючи інтертекстуальний зв'язок мію різними текстами: текстом художнъого твору $i$ текстом Біблї̈» [4, с. 21-22], що дозволяє інтерпретувати готові біблійні текстові конструкції як прецеденти до художнього паралелізму, що виконують потужну функцію протиставлення й опозиціонування, а також по-особливому сакралізують художній простір. Так, найпромовистіше у романі заявлений образ Христа, якого С.Процюк означує іншими рівновеликими онімами - Розіп'ятий, Маленький Білий Хлопчик, Спаситель, який здатний визволити героїв від тотемопоклоніння / тотемоколінкування / тотемоіделогізування / тотемозалежності як комплексу деструктивних сил. «Але з тобою, скрізъ $i$ завжди, як охоронна грамота, твій Маленький Білий Хлопчик. Навіть коли ми зчорніли $і$ прогнили наскрізь, його траурна блідість ще дае шанс для відродження» [1, с.37-38], - стверджує С.Процюк у романі, возвеличуючи подвиг Христа-Спасителя. Дискурс спасіння і прозріння у творі увиразнюється цитатою з Нового завіту «се е кров моя Нового завіту, що за вас $i$ за багатъох проливаеться на відпущення гріхів» (письмівка автора - А. Ч.) [1, с. 183], що є потужним інтелектуальним і сакральним тлом у процесі віронавернення й духовного очищення героїв.

Виразного інтертекстуального біблійного звучання у романі «Тотем» додає згадка про Содом i Гоморру як промовистої ремінісценції на буття аморального індивіда у романі С.Процюка 
має широкий арсенал супровідних ідіоматичних асоціацій (неправі, сифілітики, тлінь, тля, безсиле сладострастя), що увиразнюють мотиви марнотності, гріховності, облудливості людини, яка страждає на відступництво, зневіру, психічне й фізичне занепащення, віддаляючись від Божественного у собі. Як стверджує О. Малікова, «важсливою рисою біблеїзів є функиія осмислення моралъного ідеалу, який $\epsilon$ важливим для ідейного розуміння твору $i$ апелюе до совісті людини, ї світогляду, дозволяе відійти від окремого історичного національного та звернутися до загальнолюдсъкого, що уособлюеться у духовності кожної людини $i$ виходить за рамки сюжету твору» [5, с.91], аргументуючи функціонування використаних С.Процюком біблеїзмів для підвищення моральної значимості віри в Розіп'ятого, очищення і спокуту віронавернених героїв в ідейному спрямуванні роману. Визнання «житія Розіпятого» [1, с. 21] рятує людину від деструкції, вираженою метафорою Содом і Гоморри. Використані С. Процюком біблеїзми у романі виступають моральними орієнтирами для інтерпретації думок і вчинків героїв, які свідомо займають позиції віровідступників (Віктор, батько Віктора) чи віросповідників (Марія, Владислава, Микита).

Ужиті у тексті роману С. Процюка «Тотем» біблеїзми продукують появу своєрідної дворівневої інтертекстуальності - інтертексту в інтертексті, для якого джерелом є не власне текст-донор, а розмисли над текстом-донором, текстом-прецедентом. Так, вдаючись до художнього осмислення біблеїзму Содом і Гоморри, автор твору обережно підводить реципієнта до думки, що душевна деструкція, проявлена віровідступництвом, блудом, хтивістю, гріховністю, інстинктивністю й аморальністю призводить до виродження людини, що наближається до свого не-буття, вираженого ремінісценцією на фантастичний твір Г. Уелса «Машина часу». Елої і мерлоки як представники позалюдської раси вдаються до наймерзенніших учинків - канібалізму й садизму, що загрожує й деяким героям роману С.Процюка (Віктор, батько Віктора, Михайло Крещук), які деморалізуються і дегенералізуються.

На противагу праведності й сподвижництву Христа у тексті твору алюзійно функціонують імена історичних постатей, виразно девіантних і збоченних у своїй поведінці - Калігула, Маодзедун, Нефертіті, з якими асоціюють блуд, переступи, хтивість, безчесність, аморальність поведінки. Посилання на згаданих історичних постатей увиразнює мотив гріхопадіння та віровідступництва, продукований двома центральними персонажами - Віктором та його батьком як виразно здеморалізованими персонажами, чиї світоставні категорї 
88 Літератури світу: поетика, ментальність і духовність. 2020. Bип.14

визначалися нечистивістю, розпусністю, аморальністю, потягом до психологічного й фізичного мазохізму. «Міг же біснуватий трагік Калігула виклично трахати сенаторсъких дружин чи віддавати накази про усічення голови нездарним, на його думку, поетам. I для Калігули такі речі ставали буденними. Він займався переступами від нудъги, шукаючи ліків у вилитіи крові свіжих трупів, у кроволюбстві чи у збезчещенні шанованих мотрон $i$ навіть мотронї̈в» [1, с. 95], - зауважує С. Процюк у романі, спаралелізовуючи життєві позиції та світоуявлення здеморалізованих Віктора та його батька з життєвими принципами здеградованих історичних постатей. Хтивість, безвідповідальність, плекання тваринницьких мазохічних інстинктів, безвільність, зрадливість, асоціальність, байдужість та апатичність до ближніх спонукало до плекання деструктивного тотему гріха й розпусти, інтертекстуальними символами якого у романі постають Калігула, Маодзедун, Нефертіті.

Дискурс чоловічої зрадливості й сексуального невігластва породжують алюзії на Казанову, Дон Жуана й ловеласів як збірного поняття розбещеності й хтивості, що у романі С. Процюка відповідають за мотив авантюризму, інтимізуючи сюжет. Незчисленні сексуальні стосунки батька Віктора спровокували появу особливого культу любові й інтиму, виформувавши власну філософію любові, ґрунтовану на безвідповідальності, хтивості й зневазі до сімейних цінностей. Розбещенність і вседозволеність у сексуальних стосунках із жінками склали основу моральної деструкції героя, призвівши до лицемірства й облудливості думок і почуттів героя.

Найбільш згубного впливу на процес психологічної ідентичності героїв роману С. Процюка справляє алюзійний образ Йозефа Менгеле, що у творі виступає смертоносною метафорою, яка веде до занепащення, відчаю, відступництва, здеморалізування персонажів. Йожеф менгеле у романі виступає комплексом людських страхів і неврозів, що деструктурують людину, нещадно інфіковану цинізмом, розбещеністю, віровідступництвом, аморальністю й хтивістю, споріднюючись з іншою промовистою метафорою ляльки у романі С. Процюка «Руйнування ляльки» як провідного психодеструкта, породженого низкою травм, страхів, неврозів.

В історії людства ХХ ст. лікар концтабору Освенціма Йозеф Менгеле відомий як Ангел Смерті, який проводив жахливі експерименти з тілами й психікою ув'язнених, фізично винищуючи їх. У романі С.Процюка «Тотем» йожеф менгеле є алюзією на автодеструктивні програми персонажів, які свідомо обирають 
шлях руйнації, здеморалізування й виродження своїми вчинками й поведінкою. Герої, глибоко травмовані й уражені численними страхами, тривогами, неврозами, аморальними думками і вчинками, плекають у собі появу йожефа менгеле, що $\mathrm{\epsilon}$ «всюдu $i$ ніде, $y$ мозкові $i$ правій нириі, під нігтями $i$ віями. Він - шибеник $i$ пустун, упир-порфоріст і знесилений нариис. Він, людино, е твоїми сумнівами і страхом, неврозами і психозами, твій приватний, твій кишеньковий йожеф менгеле...» [1, с. 37], - стверджує С. Процюк у романі. Алюзія на Йозефа Менгеле активно протиставляється алюзї̈ на Спасителя, увиразнючи мотив вибору героїв, які мають шанс отримати просвітлення, сповідуючи життя і подвиг Христа, або здеградувати, піддавшись тиску йожефа менгеле. Особисті трагедії, поразки і невдачі героїв роману становлять концептуальне ядро, вихідний пункт у важливому екзистенційному виборі: викорінити чи плекати у собі йожефа менегеле як своєрідної спокуси, що веде до деструкції особистості. Як доводить роман С. Процюка, межові ситуації, в яких опинялися герої у різний час (розлучення і зради як психотравмуючі явища у житті Марії і Віктора; незчисленні любовні пригоди й гріхопадіння батька Віктора; розчарування у коханні у житті Владислави; нарцисизм, подружні зради і бізнесові проблеми у житті Микити), спонукали персонажів до свідомого вибору психофізичного не-буття чи спасіння у вірі, любові, мудрості і спокої: «Де витає аура білокрилля, неминуче шукайте чорнокрилого відсвіту, де заспокоює цілительсъкою рукою метафізична принцеса, обов'язково існує незримий слід иупкої тисячорукості сардонічного лікаря... » [1, с. 177]. Перемога особистісного (кишенькового, приватного, за С. Процюком) йожефа менгеле призводить до втрати своєї ідентичності, людської подоби, божественного у собі, деформуючи правильні ціннісні установки й орієнтири у житті героїв роману.

Виразного інтертекстуального звучання у романі С.Процюка «Тотем» набувають епіграфи, що, як відомо, виступають виразниками паратекстуальних відношень. Обрані автором епіграфи до розділів є своєрідними мікропретекстами до ідейного спрямування уривку роману й вступають у координаційні відношення 3 центральною ідеєю твору, виражаючи суголосність авторських роздумів із цитованим. I. Гринишина i Т. Марченко зауважують, що «вибір епіграфа свідчить про певну близъкість естетичних позищій автора цъого тексту й творчості або окремого тексту того, чиє слово обрано для епіграфа» [6, с.34], відтак епіграфи у романі С. Процюка у сконденсованому вигляді виражають мінісюжет розділу, відзначаючись 
випереджальним характером інформування змісту й альтернативізують авторський художній матеріал. Так, скажімо, епіграфом до одного 3 розділів роману обрано слова М. Фуко «ии здатні ми звілънитися від впливу творчої $і$ руйнівної монархіӥ статевого тягаря. . чи зуміємо ми повірити у свободу дї статевого закону, який своӥми вольнощами maк мордуе людину» [1, с. 105], що увиразнює інстинктивність поведінки та хтивість Віктора, який травмує своїм сексуальним мазохізмом і психологічним тиском Владиславу, руйнуючи здорові уявлення дівчини про кохання.

«Чужий голос» М. Фуко гармонійно входить у наративну стратегію розділу і роману С.Процюка загалом, акцентуючи на наболілих питаннях моралі й поведінки героїв. Слова М.Фуко додають вагомих психоаналітичних штрихів до інтерпретації патологічних стосунків Владислави і Віктора, увиразнюючи залежність людини від деструктивного тиску сексуальних інстинктів і непомірної хтивості. Мазохізм психологічної залежності Владислави від Віктора полягає в одночасному відчутті сладострастя й ненависті до свого коханого, у безвільності й безсилості протистояти патологічним стосункам, грунтованим на сексуальному потягові: «Люблячи, починаю ненавидіти Віктора. Ох, він мене любить, безперечно, але така «вірна» пристрасть е радие одержимістю, за допомогою якоӥ він втікає від себе, бо йому ніде приткнути власну душу, що блукає у космічному хаосі для неприкаяних. Це не любов, яка несе умиротворення, а темна пристрасть, що виїдає мене, роблячи неподібною до себе» [1, с. 105]. Патологічність любовних та інтимних стосунків між Владиславою і Віктором принижує героїню, позиціонуючи ї̈ як жертву, залежну від погроз і маніпуляцій коханого. Владиславу жахає усвідомлення звикнути до сексуальних збочень, перетворившись у «мазохістку із очима, повними покори $і$ жадання чимраз вишуканіших знущанъ» [1, с.107], яка, однак, не в силі опиратися інстинкту статевого тягаря, про який зауважено в епіграфі до розділу, що, безсумнівно, деструктурує, дезорієнтує й деградує особистість.

Виразної інтертестуальності у романі С. Процюка набуває епіграф із поезії І. Франка «Сідоглавому». Обрані автором рядки «Я ж не люблю ïi з надмірної любови» доповнюють дискурс національного у творі, увиразнюючи мотив стражденного, пасивного патріотизму, що на прикладі вчинків деяких персонажів (Михайла Юркевича, Владислави) наближається до квазіпатріотизму. Епіграф із поезї I. Франка виступає гіпертекстом, текстом-донором для подальших художніх розмислів 
С. Процюка про Україну й вияви національного у світоставленні й світоуявленні українців, що здеградовані й стравматизовані багатьма соціально-політичними обставинами, що призвело до психологічної дезадаптації та деструкції українця на різних рівнях його становлення, зокрема й власне національному. Ймовірно, негативне ставлення I. Франка до невігластва, нерішучості й повільності у просуванні національних ідей як реальних недоліків націоналізму суголосна авторським уявленням про дискурс національного, витворений героями роману «Тотем». Як стверджує Р. Голод, «Йому (Іванові Франку. - А. Ч.), як і багатъом іншим, реальним, а не формальним, українсъким патріотам інколи ставало соромно за свій народ, за його повільне просування до землі обітованої» [7, с. 227], що підсилює уявлення С. Процюка про стан націоналізму-патріотизму в Україні у романі «Тотем». Рядки з Франкової поезії продукують сум і біль за стражденну Україну, зневолену передусім невіглаством, дріб'язковістю і розгубленістю самих українців. «Бо ми всі нагадуємо свою країну. Із гарячковими першопорухами $і$ відсутністю терпіння. Із п'яною мелодраматикою і тверезою розгубленістю. Із еклектичним тавром на депресивному чолі. Із (подекуди) облудливою повагою та (більш поширеною) потаємною ненавистю до власної духовної еліти» [1, с. 183], - зауважує С. Процюк у романі. Відтак промовистий епіграф набуває виразності й актуальності у зв'язку з нагальною потребою переосмислення своєї національної сутності через позбавлення від «еклектичного тавра», рабськості, дріб'язковості, жертовності, двоєдушшя, депресивності й пасивності. Розчарування, зневіра й песимізм в оцінці національного дискурсу I. Франка виразно зчитується підтекстово й у романі С. Процюка, який, ймовірно, розділяє погляди українського письменника щодо українців, слабодухих, безвільних, апатичних і депресивних, якими є герої роману «Тотем», резонуючи 3 позицією І. Франка: «I тому повторюю: не люблю русинів. Так мало серед них знайшов я справжніх характерів, а так багато дріб'язковості, вузъкого егоӥзму, двоєдушності й пихи, що справді не знаю, за що я мав би їх любити, незважаючи навіть на ті тисячі більших і менших шпильок, які вони, не раз з найкращим наміром, вбивали мені під шкіру» [8, с. 30]. Вимогливість і критичність у національному питанні I.Франка зумовлена надміром тривоги за долю України, соромом за кволість і поступливість українців, нетерпимістю до фальшу й квазіпатріотизму, що $є$ свідченням істинного, реального почуття любові до країни, що спонукає до пробудження національної свідомості й ідентичності й у героїв роману 
С. Процюка, які мають передусім вилікувати себе, щоб підняти Україну, позбавивши її страху, невизначеності, залежності, безликості. У контексті Франкових розмислів розділ у романі С. Процюка набуває промовистого історіософського звучання, увиразнюючи національний дискурс.

Висновки і перспективи подальших досліджень. Отже, у романі С.Процюка «Тотем» виразно функціонують антропоніми, виформовуючи потужне інтертекстуальне тло твору. Функціональне навантаження онімів, що виступають промовистими алюзіями, розкрито системою стійких уявлень й асоціацій, що нюансують, додатково інформують та розширюють інтерпретаційне поле імен як кодів до осмислення персонажів роману. Інтертекстуального звучання додає й художня інтерпретація низки історичних постатей (Калігула, Маодзедун, Нефертіті), які своїми життєвими прикладами символізують хтивість, безвідповідальність, плекання тваринницьких мазохічних інстинктів, безвільність, зрадливість як базових рис удачі Віктора, батька Віктора, частково Владислави та Михайла Юркевича. Інтертекстуальності роману С. Процюка додає потужне біблійне тло твору, посилання на цитати зі Святого Письма, промовисті біблеїзми, звернення до життя Спасителя, що виступають моральними орієнтирами для інтерпретації думок і вчинків героїв, які свідомо займають позиції віровідступників (Віктор, батько Віктора) чи віросповідників (Марія, Владислава, Микита).

Деструкція людської особистості у роману С. Процюка «Тотем» виражена через низку алюзійних образів, що також виконують інтертекстуальну функцію. Так, розбещеність, сексуальна і моральна безвідповідальність, авантюризм і зрадливість підсилені образами Дон Жуана, Казанови, ловеласа, які інтимізують оповідь, увиразнюючи мотив людського гріхопадіння. Дискурс особистісної деструкції посилює також алюзія на образ нацистського лікаря-експериментатора Йозефа Менгеле, який у структурі роману С. Процюка «Тотем» мотивує появу руйнівної для людської психіки і здоров'я тотемозазалежності, тотемоідеології, що спонукає героїв до віровідступництва, відчаю, провокуючи появу страхів, неврозів, патологічних форм поведінки, руйнуючи здорові принципи і цінності людської життєдіяльності.

\section{Література}

1. Процюк С. Тотем. Івано-Франківськ: Тіповіт, 2007. 192 с. 
2. Пьего-Гро Н. Введение в теорию интертекстуальности. М. : Изд-во ЛКИ, 2008. 240 с.

3. Гальперин И. Текст как объект лингвистического исследования. М. : Наука, 1981. 138 c.

4. Єщенко Н., Бондаренко Ю. Біблеїзми у художньому тексті (на матеріалі української прози XX-XXI ст.). Науковий вісник Міжнародного гуманітарного університету. Серія: Філологія. 2017. № 30. T. 1. C. 21-25.

5. Малікова О. Біблійний інтертекст у художньому тексті. Проблеми семантики, прагматики та когнітивної лінгвістики: збірник наукових праць. 2005. Вип. 8. С. 85-94.

6. Гринишина I., Марченко Т. Інтертекстуальність та їі роль в аналізі літературного твору. Філологічні науки. Літературознавство. 2012. № 12. C. 31-35.

7. Голод Р. Націоналізм та інтернаціоналізм у системі історіософських поглядів Івана Франка. Прикарпатський вісник НТШ. Слово. 2015. № 2 (30). С. 217-231.

8. Франко І. Зібрання творів: У 50 т. Т. 31. Київ : Наук. думка, 19781986. $596 \mathrm{c}$. 